\title{
Treatment of polluted river water by a new constructed wetland
}

\author{
${ }^{1 *}$ D. F. Juang; ${ }^{2}$ P. C. Chen \\ ${ }^{1}$ Department of Healthcare Administration, Meiho Institute of Technology, 24F, 230, Ming-Chuan Second Road, \\ Kaohsiung 806, Taiwan \\ ${ }^{2}$ DHV Planetek Co., LTD., 4F, 505, Chung Shan Second Road, Kaohsiung 801, Taiwan \\ Received 22 July 2007; revised 5 August 2007; accepted 25 August 2007; available online 1 September 2007
}

\begin{abstract}
A new constructed wetland was built to purify one polluted river in Taiwan, and this study was conducted to evaluate the treatment efficiency of the wetland. Due to the very limitation of available budget, several water quality items, which were stipulated by Taiwan's Environmental Protection Administration for rivers, in the influent and effluent of wetland were analyzed and evaluated. These items included water temperature, $\mathrm{pH}, \mathrm{DO}, \mathrm{BOD}_{5}, \mathrm{TSS}$, and $\mathrm{NH}_{4}^{+}-\mathrm{N}$. The results showed that the average removal rates of total (unfiltered) $\mathrm{BOD}_{5}$, TSS and $\mathrm{NH}_{4}^{+}$- $\mathrm{N}$ were $36.9 \%, 71.8 \%$ and $47.1 \%$, respectively. With the HRT more than 3.4 days, the wetland could treat the polluted river water effectively. Longer HRT in this wetland appeared no obvious improvement on the removal rate of TSS or $\mathrm{NH}_{4}^{+}-\mathrm{N}$. However, BOD removal rate increased while the HRT (Hydraulic Retention Time) increased to about 5 days. In this wetland, the calculated mean firstorder reaction rate constant $\left(k_{T}\right)$ for $\mathrm{BOD}_{5}$ was 0.15 /day with a standard deviation of 0.13 /day and for $\mathrm{NH}_{4}{ }^{+}-\mathrm{N}_{\text {was }} 0.24$ / day with a standard deviation of 0.18 /day. It is also concluded that there is a linear proportional relationship between BOD concentrations in the effluent of wetland and its influent mass loading rates, with the coefficient of determination $\left(\mathrm{R}^{2}\right)$ of 0.6511. Similar result was seen for $\mathrm{NH}_{4}^{+}-\mathrm{N}$ as well, with the coefficient of determination $\left(\mathrm{R}^{2}\right)$ of 0.5965 . TSS removal rate was found to be linearly proportional to its influent mass loading rate, with the coefficient of determination $\left(\mathrm{R}^{2}\right)$ of 0.4875 .

Key words: Constructed wetland, ecological treatment, loading rate, macrophytes, polluted river, river water purification
\end{abstract}

\section{INTRODUCTION}

Constructed wetlands can serve as wastewater treatment systems and always consist of shallow ponds or channels planted with aquatic macrophytes. They can treat a variety of wastewaters by the microbial, biological, physical and chemical processes (Hamilton, et al., 1997; Reed, 2000; USEPA, 2000a; García, et al., 2004; Voeks and Rahmatian, 2004). Kovacic, et al., (2006) applied two wetlands to effectively reduce agricultural non-point source pollution, such as nitrogen, before it entered a lake. One of the wetlands, with average retention time between 10 and 14 days and average total $\mathrm{N}$ loading between 38.8 and $61.6 \mathrm{~kg} /$ year, indicated the average total $\mathrm{N}$ removal rate of 23 to $42 \%$. Both organic and nitrate nitrogen appeared higher removal rates in this wetland. However, it was found that the average removal rates of ammonium nitrogen were negative. Similar results were found in another wetland with average retention time between 6.5 and 8 days and average total $\mathrm{N}$ loading between 294.3 and $358.5 \mathrm{~kg} /$ year. Also, a similar result of effective nutrient removal from a lake by two wetland

즌. Corresponding Author Email: x2060@email.meiho.edu.tw Tel.: +886-8-7799821; Fax: +886-8-7780673 cells was also found by Coveney et al., (2002). Although many researchers have recently studied a variety of pollution sources in river water or in the plants of aquatic ecosystems (Alam, et al., 2007). Green, et al., (1996) used pilot-scale constructed wetlands to treat the secondary effluent from a sewage treatment plant for river reclamation. The results of their study showed that the removal of BOD and SS was very efficient with the hydraulic retention time of 4 to 15 days and BOD loading of 1 to $5.5 \mathrm{~kg} / 0.1 \mathrm{ha} /$ day (= 1 to $5.5 \mathrm{~g} / \mathrm{m}^{2} /$ day) The monthly average BOD removal rate was higher than $70 \%$, and the monthly average SS removal rate was higher than $85 \%$. However, they also found that the removal efficiency of the nitrogen and phosphorus compounds varied within a very wide range from $95 \%$ to $0 \%$. Jing, et al., (2001) reported that constructed wetlands could effectively remove the BOD, suspended solids and nutrients from highly polluted river water. Sakadevan and Bavor (1999) also concluded that the treatment efficiency of pollutants in a constructed wetland could be improved by decreasing the hydraulic loading or by increasing the hydraulic retention time. The first order reaction equation used to express the removal of $\mathrm{BOD}_{5}$ and $\mathrm{NH}_{4}{ }^{+}-\mathrm{N}$ was shown as follows. 
$\frac{C_{e}}{C_{0}}=e^{-k_{T} t}$

where $C_{0}(\mathrm{mg} / \mathrm{L})$ and $C_{e}(\mathrm{mg} / \mathrm{L})$ are the pollutant concentrations in the influent and effluent, respectively. $k_{T}\left(\right.$ day $\left.^{-1}\right)$ is the first order reaction rate constant of pollutant and $t$ (day) is the hydraulic retention time. This equation can also be expressed as the following one:

$\ln \left(\frac{C_{e}}{C_{0}}\right)=-k_{T} t$

Jing et al., (2002) obtained the first-order reaction rate constant $\left(k_{T}\right)$ of BOD in a free water surface (FWS) wetland was between 0.38 day $^{1}$ and $0.55 /$ day, and that of $\mathrm{NH}_{4}^{+}-\mathrm{N}$ was between 0.88 day $^{1}$ and 2.28/day. However, the artificial wastewater and the small-scale constructed wetlands were used in their study. Due to the river water quality in Taiwan becoming much worse in recent years, Taiwan's Environmental Protection Administration (TWEPA) has been actively propagating the natural and ecological treatment techniques for the purification of river water. Therefore, constructed wetlands have been considered as one of the techniques for the treatment of river water. In this study, we selected a large-scale new constructed FWS wetland which was built to treat the polluted water of Ho-Bou-Yu Drainage. This drainage was located in the south of Taiwan and received the runoff from swine farms or henneries and the domestic wastewater from several houses nearby. According to the water quality data of Ho-Bou-Yu Drainage from 2001 to 2004 provided by TWEPA, the monthly average $\mathrm{BOD}_{5}$ was between $5.7 \mathrm{mg} / \mathrm{L}$ and $33.5 \mathrm{mg} / \mathrm{L}$, the monthly average SS was between $10.7 \mathrm{mg} / \mathrm{L}$ and $67 \mathrm{mg} / \mathrm{L}$, and the monthly average $\mathrm{NH}_{4}{ }^{+}-\mathrm{N}$ was between $3.93 \mathrm{mg} / \mathrm{L}$ and $20.8 \mathrm{mg} / \mathrm{L}$. In this research work, we evaluated the treatment efficiency of the wetland by analyzing the water quality of the influent and effluent almost every month. Since this constructed wetland could be claimed as one of the first large-scale wetland for the treatment of river water in Taiwan, many operational data and control criteria needed to be established. However, the constructed wetlands always required a long time to reach a stable operational condition. Therefore, it is expected that the results obtained in this study could provide the operators with basic control criteria.

\section{MATERIALS AND METHODS}

Description of the FWS wetland

The water in Ho-Bou-Yu Drainage was pumped to the new constructed wetland with the total effective treatment area of 1.55 ha $\left(=15,500 \mathrm{~m}^{2}\right)$. The wetland was separated into five zones in series and its monthly average influent flow rate was operated between 3672 CMD (cubic meter per day; $\mathrm{m}^{3}$ /day) and $5352 \mathrm{CMD}$. The water depth, the area, the effective volume, and the hydraulic retention time(HRT) of each zone were described in Table 1. In the first zone, emergent and near shore macrophytes were planted and their covering rate to water surface area was about $70 \%$. Free-floating, emergent, and near shore macrophytes were planted in the second zone with their covering rate to water surface area of near $90 \%$. In both zone 3 and zone 4, all kinds of free floating, emergent, submerged and near shore macrophytes were planted. The covering rate of aquatic plants in zone 3 was about 20 $\%$, and that was approximately $10 \%$ in zone 4 . In the fifth zone, emergent and near shore macrophytes were planted, and their covering rate to the water surface area was always less than $5 \%$. All these aquatic plants in this wetland were popularly found in local. The free floating macrophytes included Nelumbo nucifera and Ludwigia adscendens, and the emergent macrophytes included Phragmites communis (Reed), Bacopa monnieri, Scripus maritimus, Cyperus alterniflius (Umbrella Plant), Typha orientalis (Cattail), and Ludwigia $x$ taiwanensis Peng. The submerged macrophytes were Ceratophyllum demersum and Egeria densa planch., and the near shore macrophytes were Hedychium coronarium koenig and Cyclosorus interruptus. After the treatment of wetland, the treated water was then discharged to the downstream of drainage by gravity.

\section{Analyses of water samples}

After the wetland was constructed and stabilized for several months, the influent and effluent water samples were collected and analyzed during a ten-month period of time. Due to the limitation of financial budget, only the influent and effluent grab samples of the wetland were collected almost twice per month. The influent grab samples were taken at the outlet of the pumping pipe (influent pipe of the wetland), and the effluent grab samples were taken at the outlet of the discharged pipe of the wetland. Water samples were measured for water temperature, $\mathrm{pH}$, dissolved oxygen (DO), $\mathrm{BOD}_{5}$, total suspended solids (TSS), and $\mathrm{NH}_{4}^{+}-\mathrm{N}$, following the methods mentioned in Standard Methods (Clesceri et al., 2001).

\section{Data analyses}

The removal efficiencies ( $r$, \%) of pollutants were calculated as:

$$
r=\frac{C_{0}-C_{e}}{C_{0}} \times 100 \%
$$


Int. J. Environ. Sci. Tech., 4 (4): 481-488, Autumn 2007

Table 1: Characteristics of FWS wetland

\begin{tabular}{llllll}
\hline \multirow{1}{*}{ Wetland Zone } & \multicolumn{5}{c}{ Flow Rate between 3672 CMD and 5352 CMD } \\
Items & Zone 1 & Zone 2 & Zone 3 & Zone 4 & Zone 5 \\
\hline Water Depth $(\mathrm{m})$ & 1.2 & 0.6 & 1.2 & 1.2 & 1.2 \\
Area $\left(\mathrm{m}^{2}\right)$ & 1800 & 1000 & 6300 & 4000 & 2400 \\
Effective Volume $\left(\mathrm{m}^{3}\right)$ & 2160 & 600 & 7560 & 4800 & 15500 \\
Hydraulic Retention Time (day) & $0.4-0.59$ & $0.11-0.16$ & $1.41-2.06$ & $0.90-1.31$ & $0.54-0.78$ \\
\hline
\end{tabular}

Table 2: Water quality data of constructed wetland

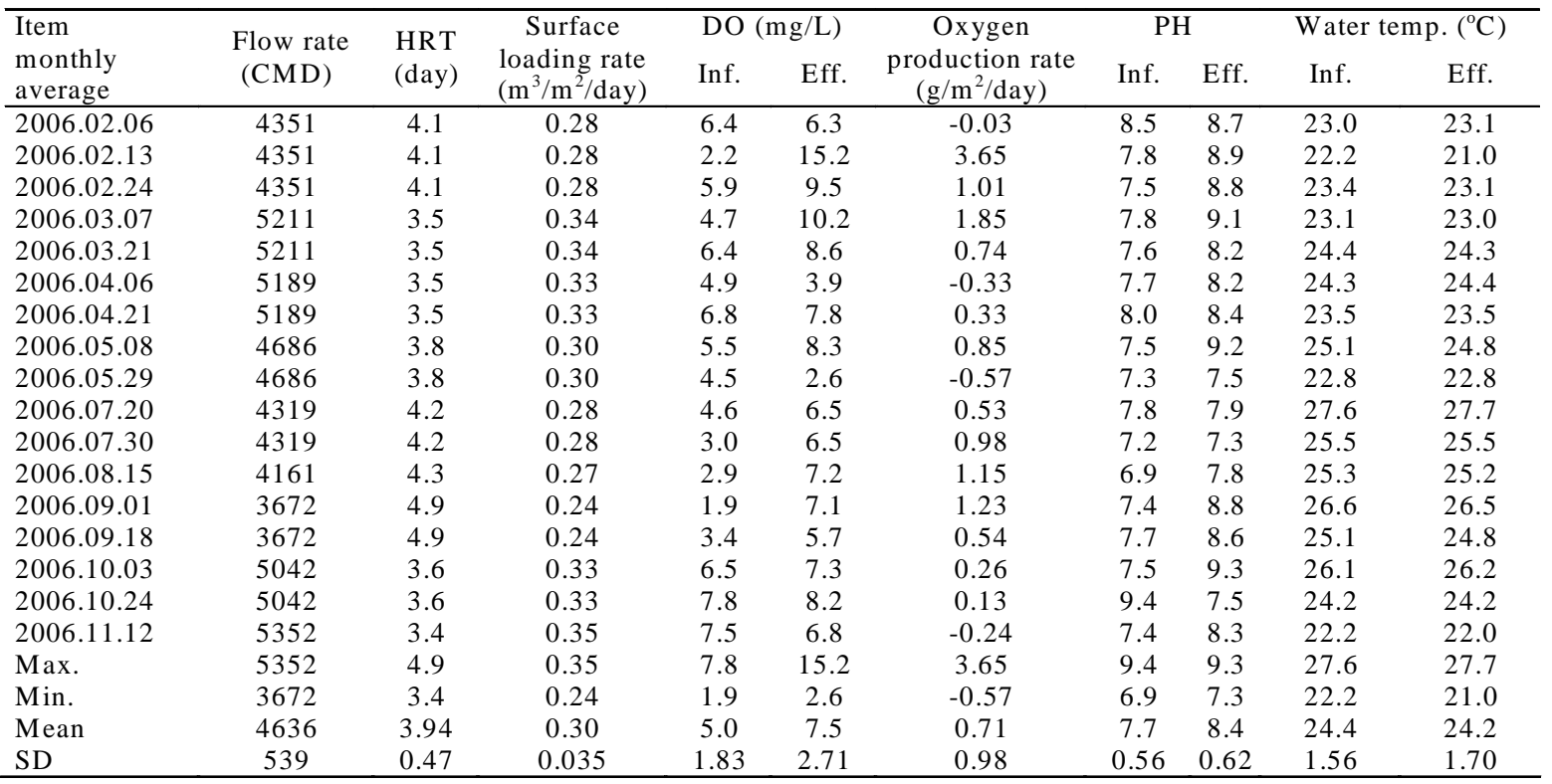

The surface loading rate $\left(S_{i}, \mathrm{~m}^{3} / \mathrm{m}^{2} /\right.$ day) and the mass loading rate $\left(M_{i}, \mathrm{~g} / \mathrm{m}^{2} /\right.$ day) were expressed as:

$$
S_{l}=\frac{q_{i}}{A} \quad \text { (4) } \quad M_{l}=\frac{C_{0} \times q_{i}}{A}
$$

where $Q_{i}\left(\mathrm{~m}^{3} /\right.$ day) is the influent flow rate and $A\left(\mathrm{~m}^{2}\right)$ is total surface area of wetland. In this study, all statistical analyses of the data were completed by using Excel or SPSS software (Jing et al., 2002; García et al., 2004; Wiessner et al., 2005), and the significance level of 0.05 was used in the ANOVA (Analysis of variance), the correlation, and the linear regression tests.

\section{RESULTS}

The water quality data of constructed wetland were shown in Table 2. During the research period, the water temperature ranged in the influent and between in the effluent. The results showed that water temperature in the influent (between $22.2^{\circ} \mathrm{C}$ and $27.6^{\circ} \mathrm{C}$ ) and in the effluent $\left(21.0^{\circ} \mathrm{C}\right.$ and $\left.27.7^{\circ} \mathrm{C}\right)$ had no obvious difference during the whole research period. Apparently, warm winter is quite obvious in the south of Taiwan. Both dissolved oxygen (DO) and pH increased after treatment.
The increase of DO concentration in the effluent was probably due to the photosynthesis of vegetation or the surface aeration in open water zones (USEPA, 2000b). It is presumed that the increase of $\mathrm{pH}$ might be due to the denitrification occurring in the sediments of wetland. However, more research work is required for better understanding of this characteristic. The oxygen production rates of this wetland were between -0.57 and $3.65 \mathrm{~g} / \mathrm{m}^{2} /$ day with a mean of $0.71 \mathrm{~g} / \mathrm{m}^{2} /$ day and a standard deviation (SD) of $0.98 \mathrm{~g} / \mathrm{m}^{2} /$ day. The surface loading rates of this wetland were between 0.24 and 0.35 $\mathrm{m}^{3} / \mathrm{m}^{2} /$ day and with a mean of $0.3 \mathrm{~m}^{3} / \mathrm{m}^{2} /$ day and a SD of $0.03 \mathrm{~m}^{3} / \mathrm{m}^{2} /$ day.

\section{Pollutant removal in the wetland}

The removal rates of $\mathrm{BOD}_{5}$, TSS and $\mathrm{NH}_{4}^{+}-\mathrm{N}$ in this wetland were illustrated in Figs. 1 to 3, respectively. During the research period, the wetland received the river water with total average concentrations of 12.4 $\mathrm{mg} / \mathrm{L}, 111.4 \mathrm{mg} / \mathrm{L}$ and $4.2 \mathrm{mg} / \mathrm{L}$ for $\mathrm{BOD}_{5}$, $\mathrm{SS}$ and $\mathrm{NH}_{4}^{+}$$\mathrm{N}$, respectively. Since the water temperature was quite stable during the whole research period, its effects on the removal rates of $\mathrm{BOD}_{5}$ or $\mathrm{NH}_{4}^{+}-\mathrm{N}$ could be 
neglected. However, the most efficient $\mathrm{BOD}_{5}$ and $\mathrm{NH}_{4}^{+}-$ $\mathrm{N}$ removal occurred in September (see Figs. 1 and 3). Fig. 4 showed the relationship between hydraulic retention time (HRT) and pollutant removal rate of wetland. Apparently, the wetland has displayed its effective treatment on the pollutants in river water while the HRT is more than 3.4 days. According to Figure 4, BOD removal rate improved more obviously at higher HRT such as 4.9 days in this study, but no obvious difference on the removal rates for both TSS and $\mathrm{NH}_{4}^{+}-$ $\mathrm{N}$ was seen at the HRT from 3.4 days to about 5 days. However, the ANOVA test results in Table 3 showed that there were no significant differences $(p>0.05)$ on the removal rates of $\mathrm{BOD}_{5}$, TSS and $\mathrm{NH}_{4}^{+}-\mathrm{N}$ with the HRT less than 3.5 days, between 3.5 days and 4.0 days, and higher than 4.0 days. During the research period, the average removal rates of total (unfiltered) $\mathrm{BOD}_{5}$, TSS and $\mathrm{NH}_{4}{ }^{+}-\mathrm{N}$ were $36.9 \%, 71.8 \%$ and $47.1 \%$, respectively.

\section{Pollutant loading rates of the wetland}

The correlations between the effluent concentrations or the removal rates of pollutants and theHRT or the loading rates of wetland system were shown in Table 4 . Apparently, BOD effluent concentration and its mass loading rate had a significant correlation $(p=0.000)$ in this wetland. Similar result was seen between $\mathrm{NH}_{4}{ }^{+} \mathrm{N}$ effluent concentration and its mass loading rate with the $p$ value less than 0.05 . A significant correlation was also seen between TSS removal rate and its mass loading rate $(p=0.002)$. Figs. 5 - 6 expressed the relationships between the effluent concentration and the loading rate of $\mathrm{BOD}_{5}$ and $\mathrm{NH}_{4}^{+}-\mathrm{N}$, respectively. The total average $\mathrm{BOD}_{5}$ and $\mathrm{NH}_{4}^{+}-\mathrm{N}$ loading rate were 3.32 and $1.29 \mathrm{~g} / \mathrm{m}^{2} /$ day, respectively. These loading rates were in the reasonable range mentioned by USEPA (2000a), which were $0.23-18.3 \mathrm{~g} / \mathrm{m}^{2} /$ day for $\mathrm{BOD}_{5}$ loading rate and $0.03-1.6 \mathrm{~g} / \mathrm{m}^{2} /$ day for $\mathrm{NH}_{4}^{+}-\mathrm{N}$ loading rate. Fig. 5 also showed the results of linear regression between $\mathrm{BOD}_{5}$ concentration in the effluent and $\mathrm{BOD}_{5}$ loading rate, and this relationship was expressed as follows with the coefficient of determination $\left(\mathrm{R}^{2}\right)$ of 0.6511 :

$$
C_{e B}=0.6434 \times M_{i B}-0.3733
$$

where $C_{e B}$ is $\mathrm{BOD}_{5}$ concentration $(\mathrm{mg} / \mathrm{L})$ in the effluent of wetland and $M_{i B}$ is the BOD loading rate ( $\mathrm{g} / \mathrm{m}^{2} /$ day). Fig. 6 also showed the results of linear regression between $\mathrm{NH}_{4}^{+}$- $\mathrm{N}$ concentration in the effluent and $\mathrm{NH}_{4}^{+}-\mathrm{N}$ loading rate, and this relationship was expressed as follows with the coefficient of determination $\left(\mathrm{R}^{2}\right)$ of 0.5965 :

Table 3: ANOVA tests for pollutant removal rates at different hydraulic retention time

\begin{tabular}{|c|c|c|c|c|c|c|}
\hline Parameter & HRT (days) & $\mathrm{n}$ & Ave. removal rate (\%) & SD & F & P value \\
\hline \multirow{4}{*}{ BOD } & $<=3.5$ & 5 & 38.7 & 23.1 & & \\
\hline & $>3.5$ and $<4.0$ & 4 & 7.1 & 59.3 & & \\
\hline & $>=4.0$ & 8 & 50.6 & 18.3 & & \\
\hline & total & 17 & 36.9 & 35.5 & \multirow[t]{2}{*}{3.974} & \multirow[t]{2}{*}{0.066} \\
\hline \multirow{4}{*}{ TSS } & $<=3.5$ & 5 & 67.4 & 24.7 & & \\
\hline & $>3.5$ and $<4.0$ & 4 & 75.1 & 11.9 & \multirow{4}{*}{0.164} & \multirow{4}{*}{0.692} \\
\hline & $>=4.0$ & 8 & 72.8 & 23.1 & & \\
\hline & total & 17 & 71.8 & 20.6 & & \\
\hline \multirow{4}{*}{$\mathrm{NH}_{4}{ }^{+}-\mathrm{N}$} & $<=3.5$ & 5 & 51.2 & 16.1 & & \\
\hline & $>3.5$ and $<4.0$ & 4 & 18.4 & 94.0 & & \\
\hline & $>=4.0$ & 8 & 58.9 & 40.2 & & \\
\hline & total & 17 & 47.1 & 52.1 & 1.466 & 0.246 \\
\hline
\end{tabular}

Table 4: Correlations between pollutant effluent concentrations or removal rates and pollutant HRTs or loading rates

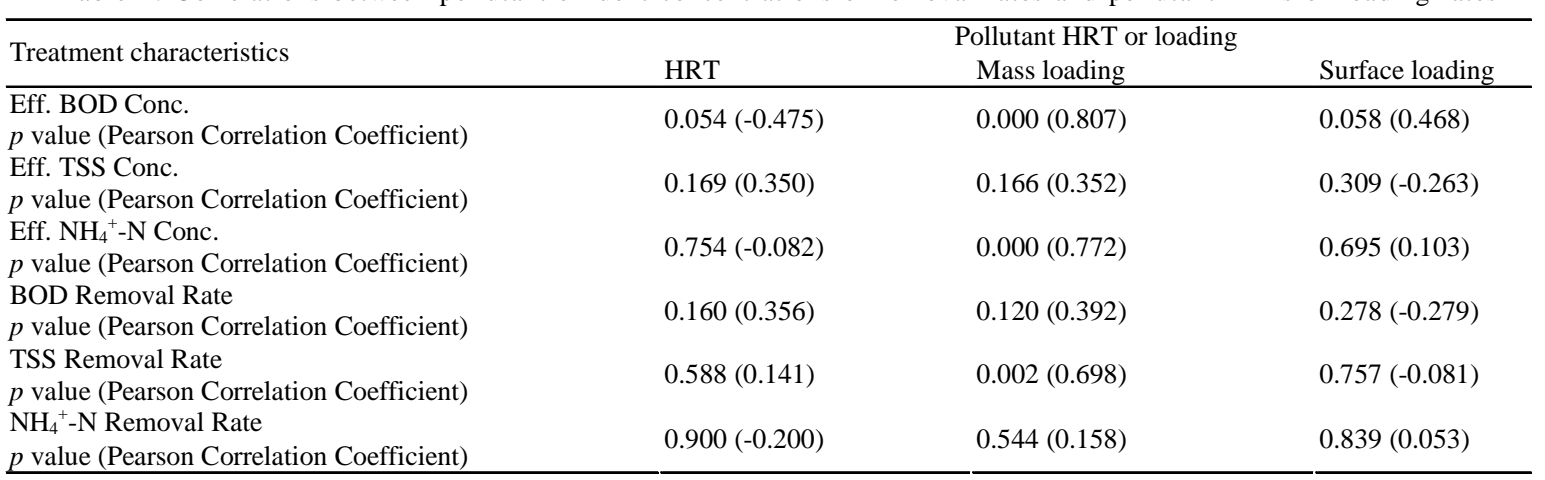




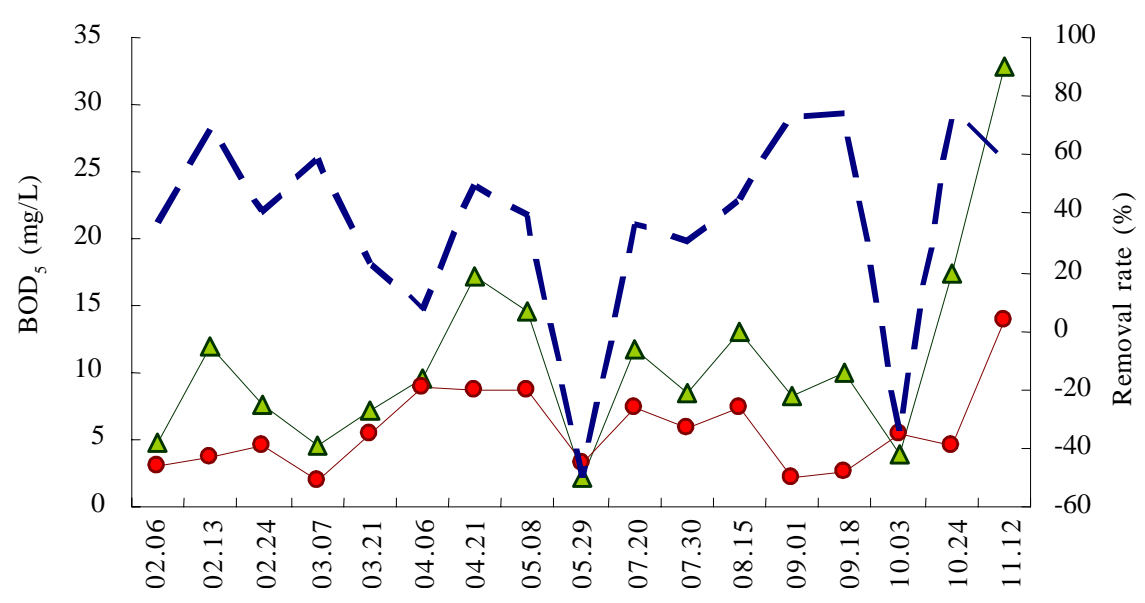

Date (2006)

Fig. 1: BOD removal rate in the wetland

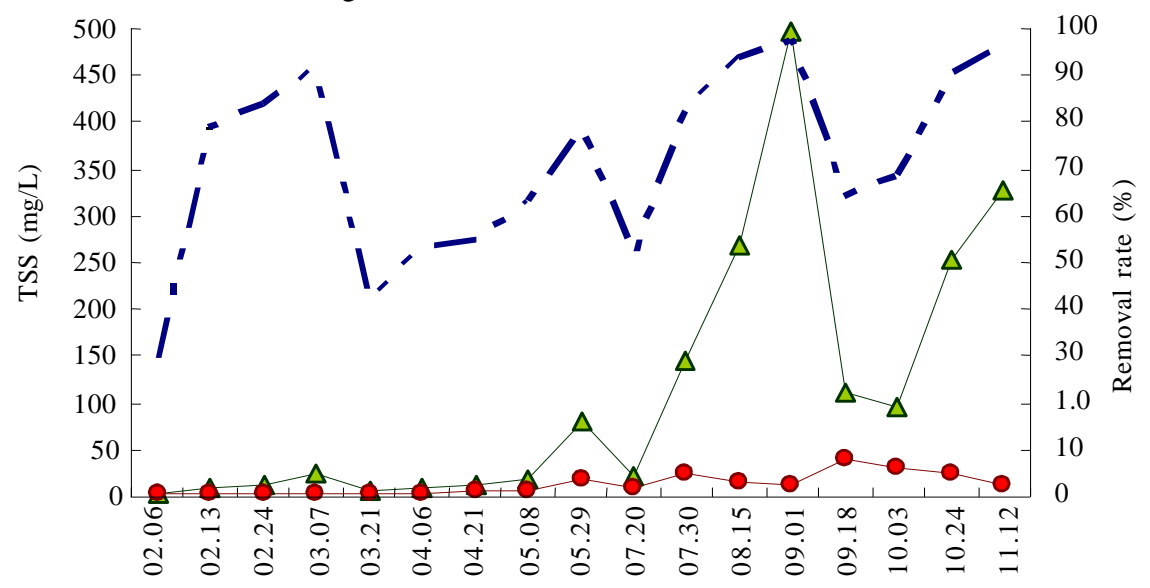

Date (2006)

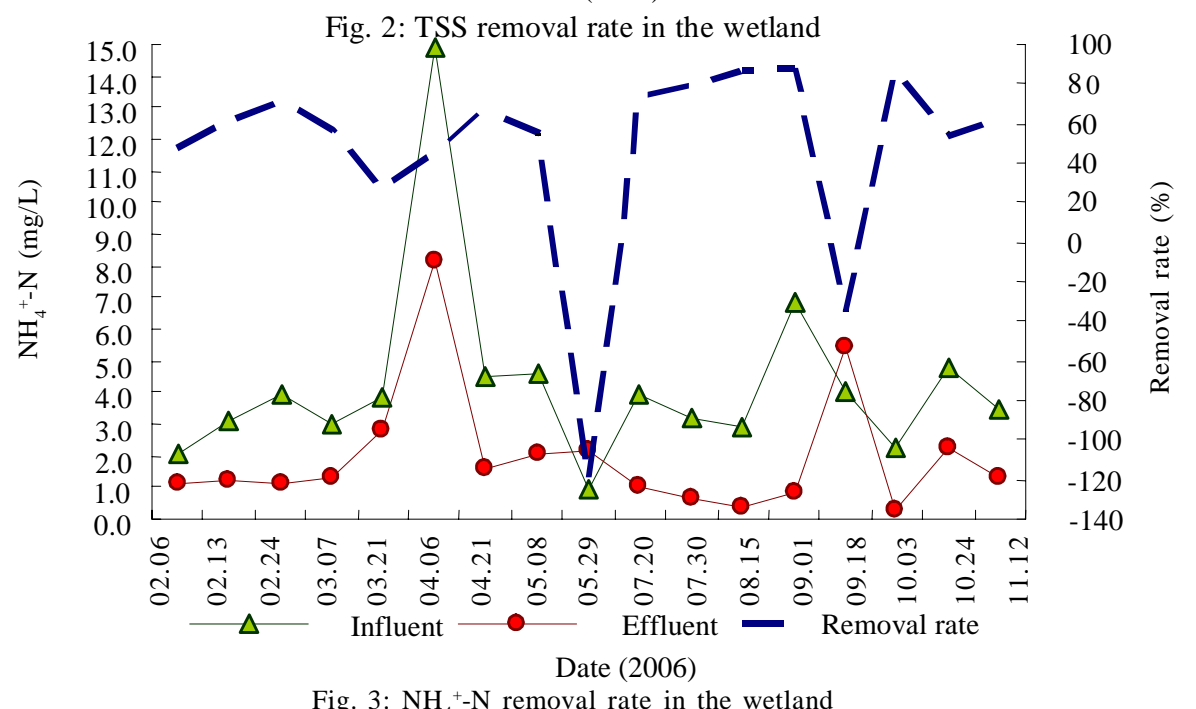

Fig. 3: $\mathrm{NH}_{4}{ }^{+}-\mathrm{N}$ removal rate in the wetland 


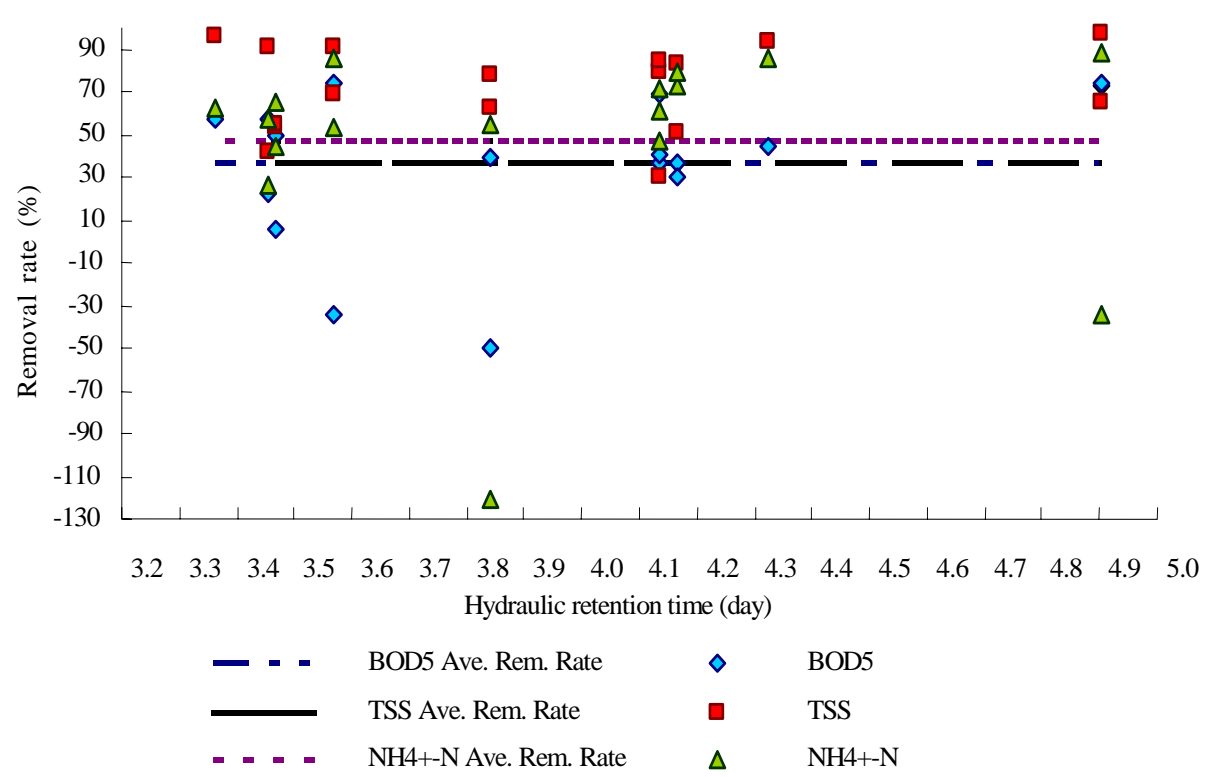

Fig. 4: The relationship between HRT and pollutant removal rate

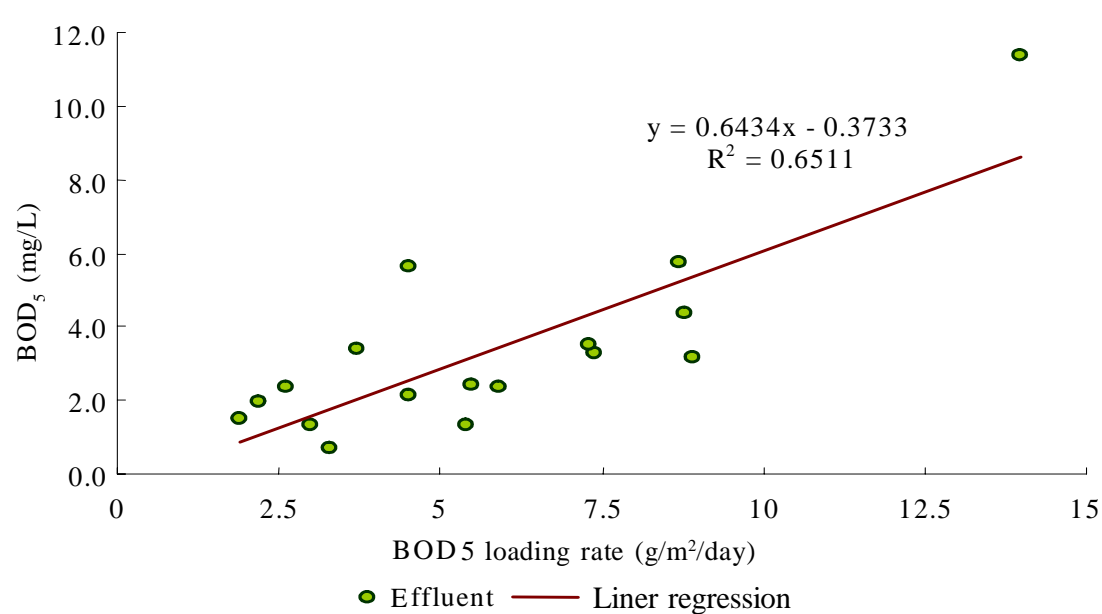

Fig. 5: Relationship between effluent $\mathrm{BOD}_{5}$ concentration and $\mathrm{BOD}_{5}$ loading rate

$$
C_{e N}=1.5128 \times M_{i N}-0.0367
$$

where $\mathrm{C}_{e B}$ is $\mathrm{NH}_{4}^{+}$-N concentration (mg/L) in the effluent of wetland and $M_{i M}$ is the $\mathrm{NH}_{4}{ }^{+}$-N loading rate $\left(\mathrm{g} / \mathrm{m}^{2} /\right.$ day). Fig. 7 illustrated the relationship between loading rate and removal rate of $\mathrm{BOD}_{5}$ and $\mathrm{NH}_{4}{ }^{+} \mathrm{N}$. It seems that the effect of $\mathrm{BOD}$ loading rates on the removal rates of $\mathrm{BOD}_{5}$ was not obvious with the hydraulic retention time in the rage of 3.4 to 4.9 days. However, $\mathrm{NH}_{4}^{+}-\mathrm{N}$ removal rates might be higher at lower loading rates. Fig. 8 showed the results of linear regression between TSS loading rate and its removal rate, and this relationship was expressed as follows with the coefficient of determination $\left(\mathrm{R}^{2}\right)$ of 0.4875 :

$$
R R_{S S}=0.3605 \times M_{i_{S}}+60.241
$$

where $R R_{S S}$ is the TSS removal rate (\%) of wetland and $M_{i S}$ is the TSS loading rate ( $\left.\mathrm{g} / \mathrm{m}^{2} / \mathrm{day}\right)$.

\section{DISCUSSION AND CONCLUSION}

The results of this study showed that the constructed wetland can be applied to purify the polluted river water although the covering rate of macrophytes to the water surface area was not high. The oxygen production rates of constructed wetlands were in the range of 0 to $28.6 \mathrm{~g} / \mathrm{m}^{2} /$ day, whereas rates of 0 to $3 \mathrm{~g} / \mathrm{m}^{2} /$ day were mostly found (Kadlec and Knight, 1996). Since the oxygen production rates of 
Int. J. Environ. Sci. Tech., 4 (4): 481-488, Autumn 2007

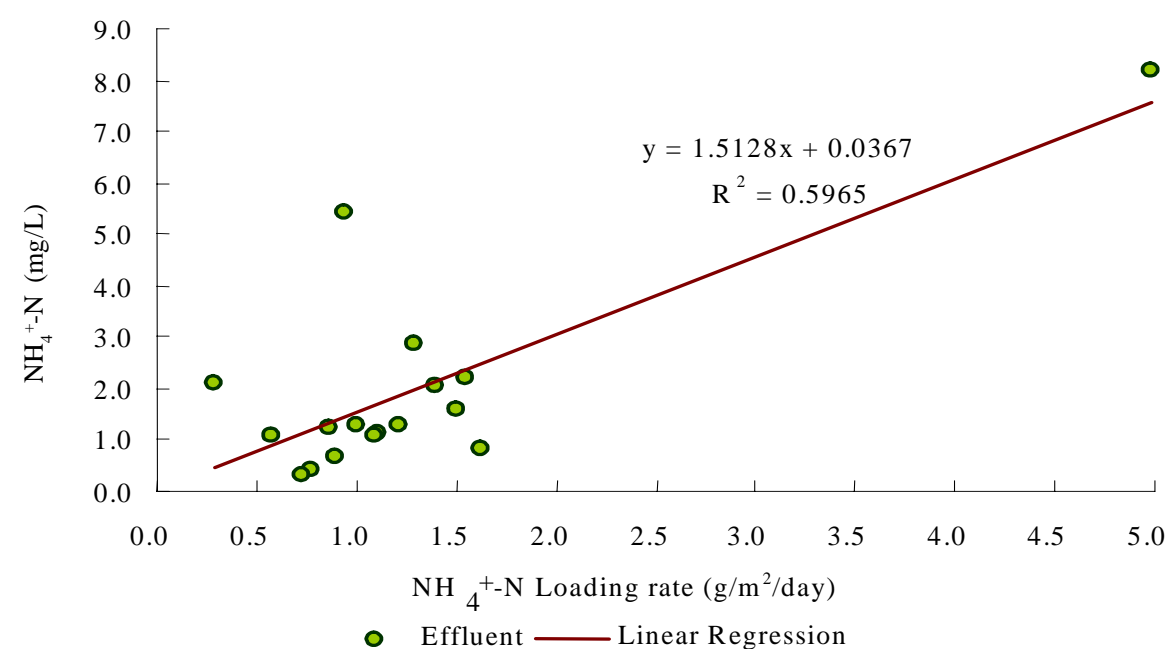

Fig. 6: Relationship between effluent $\mathrm{NH}_{4}^{+}-\mathrm{N}$ concentration and $\mathrm{NH}_{4}{ }^{+}-\mathrm{N}$ loading rate

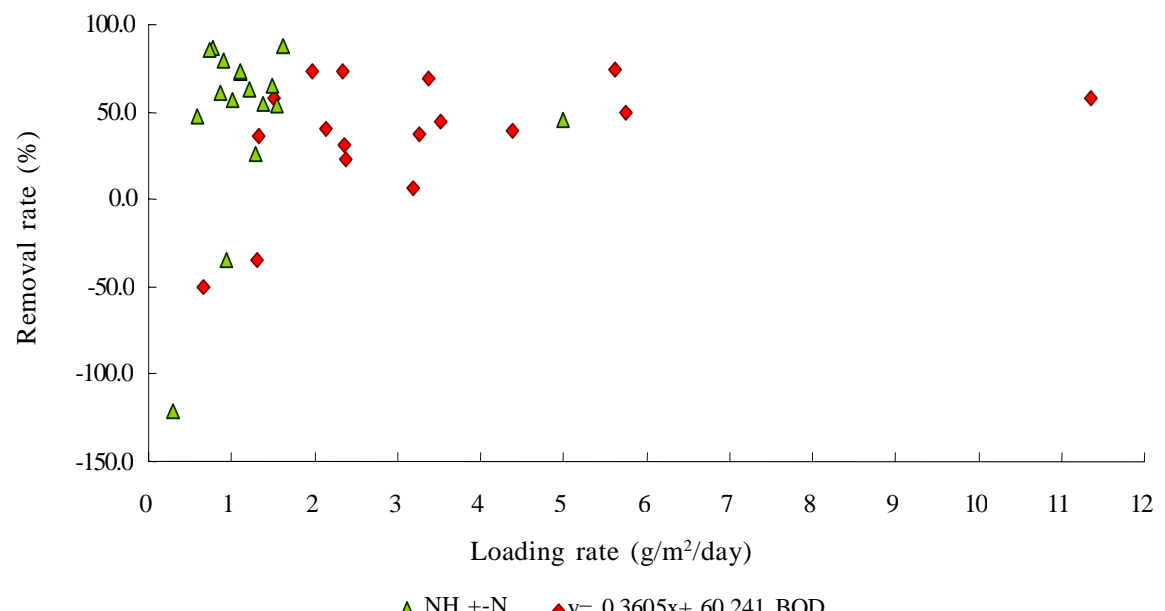

Fig. 7: Relationship between $\mathrm{BOD}_{5}$ and $\mathrm{NH}_{4}{ }^{+} \mathrm{N}$ removal rates and mass loading rates

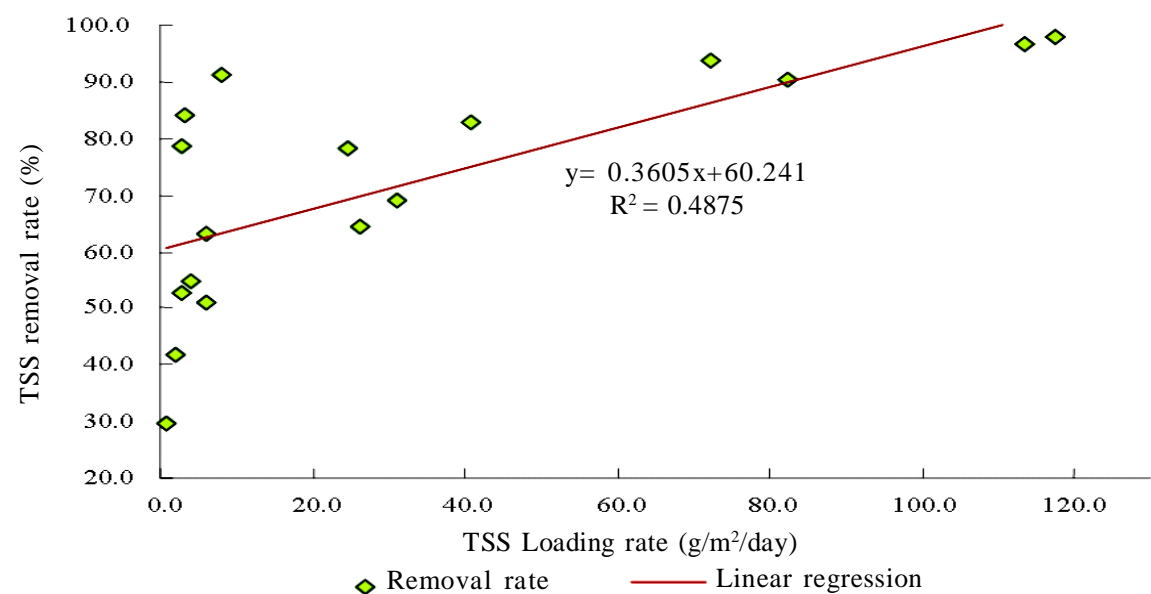

Fig. 8: Relationship between TSS removal rate and TSS loading rate 
this wetland were between -0.57 and $3.65 \mathrm{~g} / \mathrm{m}^{2} /$ day and with a mean of $0.71 \mathrm{~g} / \mathrm{m}^{2} /$ day, these values seemed to be reasonable.

The surface loading rates of this wetland were between 0.24 and $0.35 \mathrm{~m}^{3} / \mathrm{m}^{2} /$ day and with a mean of 0.3 $\mathrm{m}^{3} / \mathrm{m}^{2} /$ day. They were also in the range of 0.01 to $0.5 \mathrm{~m}^{3} / \mathrm{m}^{2} /$ daytypically applied to the FWS wetlands (USEPA, 2000b). In this study, the average removal rates of total (unfiltered) $\mathrm{BOD}_{5}$, TSS and $\mathrm{NH}_{4}^{+}-\mathrm{N}$ were $36.9 \%, 71.8 \%$ and $47.1 \%$, respectively. Since lower HRT was applied in this study, these pollutant removal rates were somewhat lower than those reported by Green et al., (1996). Basically, the wetland has displayed an effective treatment of pollutants in this drainage with the HRT more than 3.4 days, and no obvious difference of BOD, TSS, or $\mathrm{NH}_{4}^{+}$-N removal rate was seen for longer HRT up to about 5 days. This study also found that the BOD and $\mathrm{NH}_{4}^{+}-\mathrm{N}$ concentrations in the effluent of wetland will be linearly proportional to their influent mass loading rate. $\mathrm{NH}_{4}^{+}-\mathrm{N}$ removal rate was higher at lower mass loading rate, and the removal rate of TSS was linearly proportional to their influent mass loading rate. According to the equation (1) or (2), the calculated mean first order reaction rate constant $\left(k_{T}\right)$ for $\mathrm{BOD}_{5}$ was 0.15 /day with a standard deviation of 0.13 /day and for $\mathrm{NH}_{4}^{+}-\mathrm{N}$ was 0.24 / day with a standard deviation of 0.18 /day. These constants were somewhat lower than those reported by Jing, et al., (2002). Since the artificial wastewater and the small-scale constructed wetlands were used in their study, it is possible that the pollutants in the river water of this study could be more difficult to be degraded by microbes than those in artificial wastewater. Basically, this constructed wetland has still shown acceptable results on the purification of river water. The equations developed in this study will provide the operators with basic control criteria of this wetland.

\section{REFERENCES}

Alam, Md.J.B.; Islam, M.R.; Muyen, Z.; Mamun, M.; Islam, S. (2007). Water quality parameters along rivers. Int. J. Environ. Sci. Tech., 4 (1), 159-167.
Clesceri, L.S.; Greenberg, A.E.; Eaton, A.D., (2001). Standard methods for the examination of water and wastewater. American Public Health Association (APHA), American Water Works Association (AWWA) and Water Environment Federation (WEF).

Coveney, M.F.; Stites, D.L.; Lowe, E.F.; Battoe, L.E.; Conrow, R., (2002). Nutrient removal from eutrophic lake water by wetland filtration. Eco. Eng., 19(2), 141-159.

García, J.; Aguirre, P.; Mujeriego, R.; Huang, Y.; Ortiz, L.; Bayona, J.M., (2004). Initial contaminant removal performance factors in horizontal flow reed beds used for treating urban wastewater. Water Res., 38(7), 1669-1678.

Green, M.; Safray, I.; Moshe, A., (1996). Constructed wetlands for river reclamation: Experimental design, start-up and preliminary results. Bioresour. Tech., 55(2), 157-162.

Hamilton, S.K.; Sippel, S.J.; Calheiros, D.F.; Melack, J.M., (1997). An anoxic event and other biogeochemical effects of Pantanal wetland on the Paraguay river. Limnol. Oceanogr., 42(2), 257272.

Jing, S.R.; Lin, Y.F.; Lee, D.Y.; Wang, T.W., (2001). Nutrient removal from polluted river water by using constructed wetlands. Bioresour. Tech., 76(2), 131-135.

Jing, S.R.; Lin, Y.F.; Lee, D.Y.; Wang, T.W., (2002). Performance of constructed wetlands planted with various macrophytes and using high hydraulic loading. J. Environ. Qual., 31(2), 690-696.

Kadlec, R.H.; Knight, R.L. (1996). Treatment wetlands. Florida: Lewis-CRC Press.

Kovacic, D.A.; Twait, R.M.; Wallace, M.P.; Bowling, J.M., (2006). Use of created wetlands to improve water quality in the Midwest Lake Bloomington case study. Eco. Eng., 28(3), 258-270.

Reed, S.C. (2000). Land treatment systems for municipal and industrial wastes. McGraw-Hill, USA.

Sakadevan, K.; Bavor, H.J., (1998). Phosphate adsorption characteristics of soils, slags and zeolite to be used as substrates in constructed wetland systems. Water Res., 32(2), 393-399.

USEPA (2000a). Constructed wetlands treatment of municipal wastewaters. EPA Manual, EPA/625/R-99/010, USA.

USEPA., (2000b). Guiding principles for constructed treatment wetlands. EPA, USA.

Voeks, R.A.; Rahmatian, M., (2004). The providence of nature: Valuing ecosystem services. Int. J. Environ. Sci. Tech., 1(2), 151-163.

Wiessner, A.; Kappelmeyer, U.; Kuschk, P.; Kästner, M., (2005). Sulphate reduction and the removal of carbon and ammonia in a laboratory-scale constructed wetland. Water Res., 39, 46434650.

\section{AUTHOR (S) BIOSKETCHES}

Juang, D. F., associate professor, Ph.D., Department of Healthcare Administration, Meiho Institute of Technology, 24F, 230, Ming-Chuan Second Road, Kaohsiung 806, Taiwan. Email: x2060@email.meiho.edu.tw

Chen, P. C., project engineer, M.Sc., DHV Planetek Co., LTD., 4F, 505, Chung, Shan Second Road,

Kaohsiung 801, Taiwan. Email: chuchu@dhvplanetek.com.tw

This article should be referenced as follows:

Juang, D.F.; Chen, P.C., (2007). Treatment of polluted river water by a new constructed wetland. Int. J. Environ. Sci. Tech., 4 (4), $481-488$. 